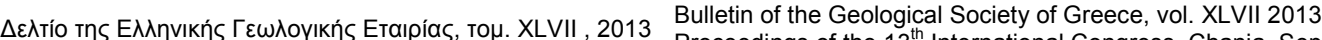


2013

\title{
COSEISMIC SURFACE DISPLACEMENT VARIABILITY IN RELATION TO LITHOLOGY
}

\author{
Rondoyanni Th. ${ }^{1}$, Lykoudi E. ${ }^{1}$ and Kalogeras $\mathbf{E}^{1}$. \\ ${ }^{I}$ National Technical University of Athens, School of Mining and Metallurgical Engineering, \\ Department of Earth Sciences, rondo@central.ntua.gr,elykoudi@metal.ntua.gr
}

\begin{abstract}
The variability of coseismic surface displacement along reactivated normal faults in the Aegean region is investigated. Seismotectonic data of past earthquakes associated with ground deformation and surface rupturing have been collected and analysed. Geological maps presenting the displacement at different sites along the fault traces have been compiled, as well as plots illustrating the corresponding relation between displacement and lithology. The main conclusion of this work is the strong correlation between regional lithology and coseismic surface displacement. Along a reactivated fault, the displacement observed in the recent geological formations is at least twice the displacement observed in the geological bedrock. It must be noted that the ratio of maximum to minimum displacement values along a certain active fault could be high as 5:1. Moreover, the potential displacements determined on the basis of existing empirical relationships, correspond to those observed in the bedrock. These findings could be taken into consideration in seismic hazard analysis during urban and engineering design.

Key words: Seismotectonics; Earthquake rupturing; Fault reactivation.
\end{abstract}

\section{Пєрі́ $\eta \psi \eta$}

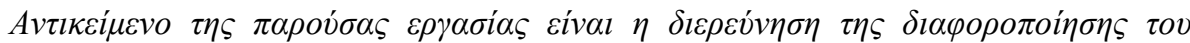

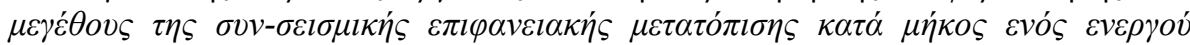

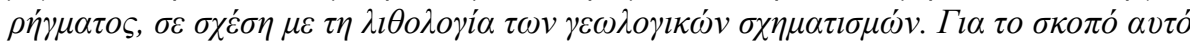



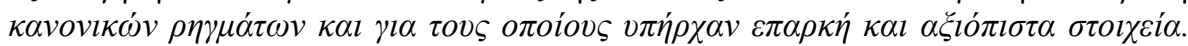

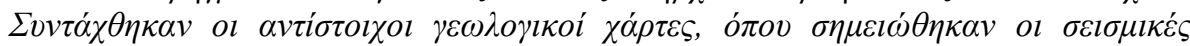

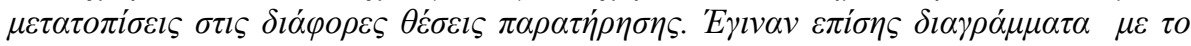





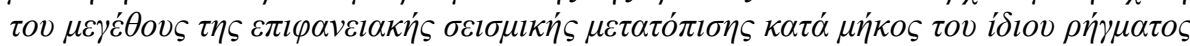

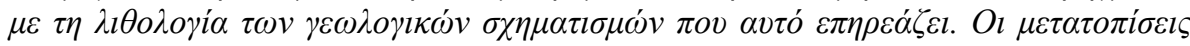





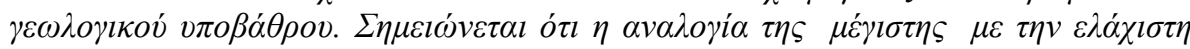

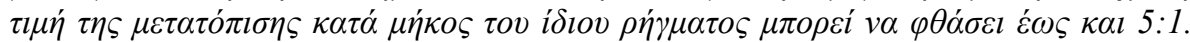

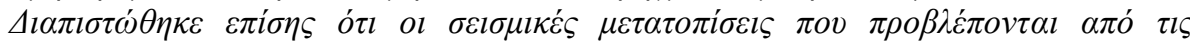



XLVII. No $2-637$ 


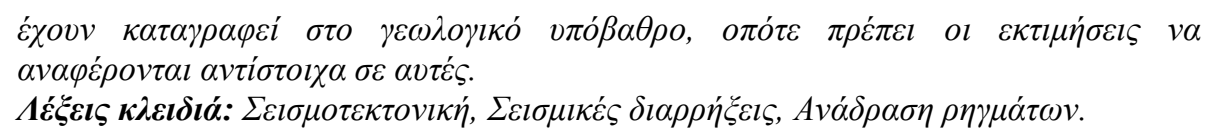

\section{Introduction}

The occurrence of surface rupturing and displacement along reactivated faults during strong earthquakes often results in severe structural damage due to additional ground deformation. Consequently, potential surface displacement is taken into consideration in seismic hazard analysis during urban and engineering design. To estimate future seismic surface displacement, many researchers have established empirical relations between fault length, earthquake magnitude and seismic displacement; the models proposed by Wells and Coppersmith (1994) based on worldwide data are the most commonly used. In Greece, the relations suggested by Pavlides and Caputo (2004) based on earthquake data of the Aegean region are also applied.

These relations give a range of values for average and maximum displacement observed during past earthquakes; however, no particular consideration is given to the variability of displacement depending on the differentiation of the lithologies crossed by the fault. Therefore, in the probabilistic hazard assessment of fault displacement dealing with shallow earthquakes, surface displacement is considered to depend mainly on fault length.

Displacement variability along fault trace has been noted by Sigbjörnsson and Olafsson (2004) for shallow strike-slip earthquakes with almost vertical fault plane, in the South Iceland Seismic Zone. Rockwell and Klinger (2011), by presenting new measurements for the 1940 and 1979 surface ruptures along the Imperial fault of Southern California, have reported that lateral slip varies substantially along fault-strike by more than $30 \%$, over distances of tens to hundreds of meters. Similar results concerning slip variability have been determined after the 1999 Izmit and Duzce earthquakes in Turkey (Barka and Akyuz, 2002). The above mentioned works are focusing on the uncertainty of the collected seismic fault displacement data and on the need for closely spaced measurements; however, they are not presenting any correlation between this variability and the lithology along the fault trace.

The purpose of the present work is to investigate the influence of the lithology, of different geological formations crossed by a reactivated fault, on the magnitude of coseismic surface displacement along this fault. Information concerning shallow strong earthquakes associated with surface faulting in the Aegean region was collected and differentiations along the faults were studied. The studied earthquakes were related to the reactivation of normal faults under an extensional stress field.

\section{Evaluation of Displacement Data}

Certain historical and recent earthquakes in the Aegean region have exhibited surface deformation and coseismic rupturing of tectonic origin. Detailed information about coseismic surface displacement is limited, due to the fact that systematic seismotectonic studies were undertaken in Greece during the last 35 years. Moreover, there are some ambiguities as to the recorded values of coseismic displacement attributed to the following factors: incompleteness of data reflecting only part of the total fault length, sparse field measurements, recording of non-tectonic deformation, inclusion of gravitational phenomena or compaction of loose sediments and even false measurements. Besides, seismic fault traces along normal faults can be mapped and measured less confidently than fault traces along strike-slip faults.

The most ancient information, in Greece, for coseismic displacement concerns the 464 B.C. Sparta earthquake with an estimated magnitude $\mathrm{Ms}=7.2$ and referred displacement about $3 \mathrm{~m}$, the largest recorded in the Greek territory (Armijo et al., 1991). Field data, but non systematic measurements, concerning coseismic displacements exist for a number of about 30 earthquakes (Papazachos and

XLVII. No $2-638$ 
Papazachou, 2003; Pavlides and Caputo, 2004). Information for the last 120 years is referred to the earthquakes of Atalanti (1894), Ierissos (1932), Larissa (1941), Corinth (1953), Sophades (1954), Aghios Efstratios (1968), Thessaloniki (1978), Almyros (1980), Acarnania (1983), Corintian Gulf (1981), Kalamata (1986), Aigio (1995), Kozani (1995), Konitsa (1996), Andravida (2008), Oichalia (2011) (Figure 1). However, accurate data enabling comparison of coseismic displacement with lithology are available for the earthquakes of Atalanti (1894), Thessaloniki (1978) and Corinth (1981). Some others, even strong and disastrous earthquakes, were associated with minor surface rupturing and vertical displacements of the order of few centimetres. As example, the cases of 1986 Kalamata and 1995 Aigio earthquakes could be mentioned (Figures 2a and 2b). This work is a first attempt towards identifying a relation between surface coseismic displacements and affected

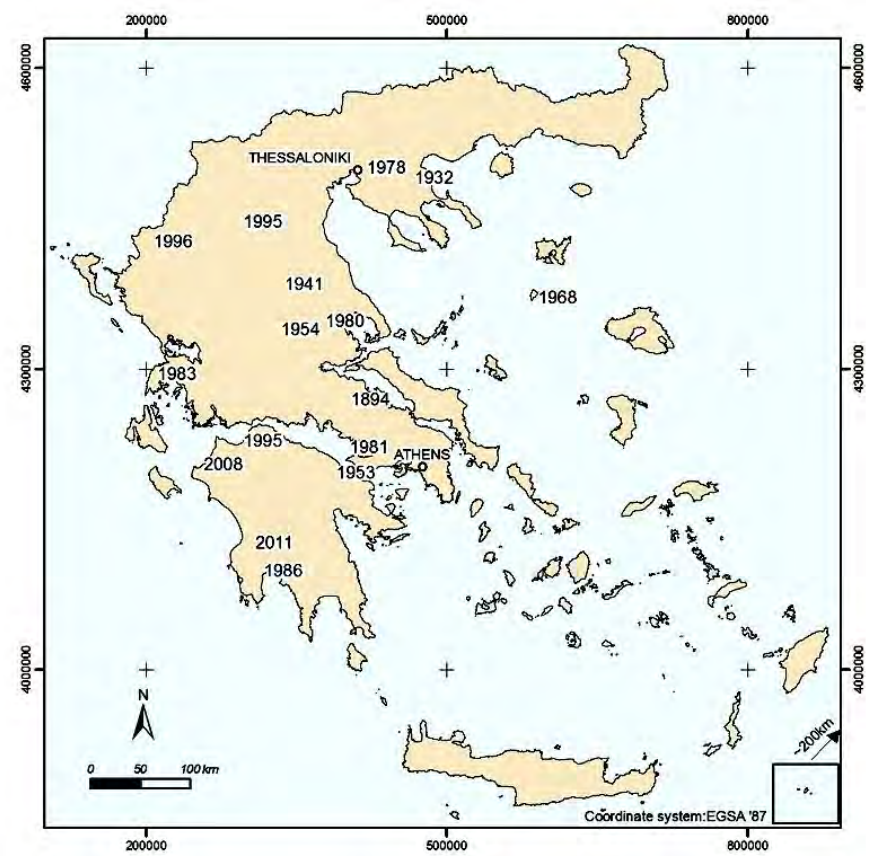

Figure 1- Map of Greece showing the year and the location of the earthquake faults.


Figure 2- Open seismic cracks, without vertical displacement, formed during the 1986 Kalamata (a) and 1995 Aigio (b) earthquakes.

XLVII. No $2-639$ 
lithologies in an extensional seismotectonic regime, like the one dominating in Greek territory. For the evaluation of the relation between seismic displacement and affected lithologies at different sites along seismic faults, seismogeological maps were compiled, as presented hereafter. In these maps, the sites where data of coseismic surface displacement are available along reactivated faults were also noted. Then, a statistical evaluation of all available data was performed on the basis of plots illustrating seismic displacements along each fault as well as seismic displacements corresponding to each lithology.

\subsection{The 1981 Corinth Earthquakes}

The 1981 Corinth earthquakes constitute a good example for the study of coseismic displacement, because, in addition to the completeness of data, surface ruptures have affected a variety of geological formations allowing valuable comparisons and evaluations. The Corinthian Gulf is an active graben structure presenting intense seismicity and a rate of extensional deformation of the order of 30mm/yr NS (Billiris et al., 1991). Many past earthquakes have been accompanied by surface rupturing (Figure 3), coastal subsidence, landslides and liquefaction. Such phenomena observed during the 1981 earthquakes, were located at the eastern part of Corinthian gulf (Koukis and Rozos, 1982). Three main events were recorded, the first on February $24(\mathrm{Ms}=6.7)$, the second on February $25(\mathrm{Ms}=6.4)$ and the third on March $4(\mathrm{Ms}=6.3)$. The geological formations affected by seismic ruptures are coastal and alluvial deposits, scree and talus cones, limestone breccias, Plio-Pleistocene formations (marls, clays, sandstones and conglomerates), flysch, limestones and dolomites, schists-phyllites and ophiolites.

During the February 24 earthquake, large normal faults were reactivated in the southern part of the Gulf (in the Perachora peninsula) and the resulting seismic ruptures followed their traces (Figure 4). The total length of surface ruptures was about $15 \mathrm{~km}$ and displacements reached a maximum of $150 \mathrm{~cm}$, usually ranging from $30 \mathrm{~cm}$ to $70 \mathrm{~cm}$. During the March 4 earthquake, seismic cracks were observed in the northern part of the Gulf (Kaparelli area), over a total length of $12 \mathrm{~km}$ (Figure 5).

The cracks were arranged in two branches, where displacements ranged from 50 to $70 \mathrm{~cm}$ (personal observations; Jackson et al., 1982). The plots of Figures 6 and 7, show clearly the difference in the magnitude of seismic displacement between the geological formations of the bedrock and those of the recent formations. Only in certain seismic cracks in Pleistocene and alluvial deposits, observed in Kaparelli area, that had a variable azimuth, the displacement was of the order of few centimeters, because these cracks represented a polydeformed transfer zone between two main fault segments.

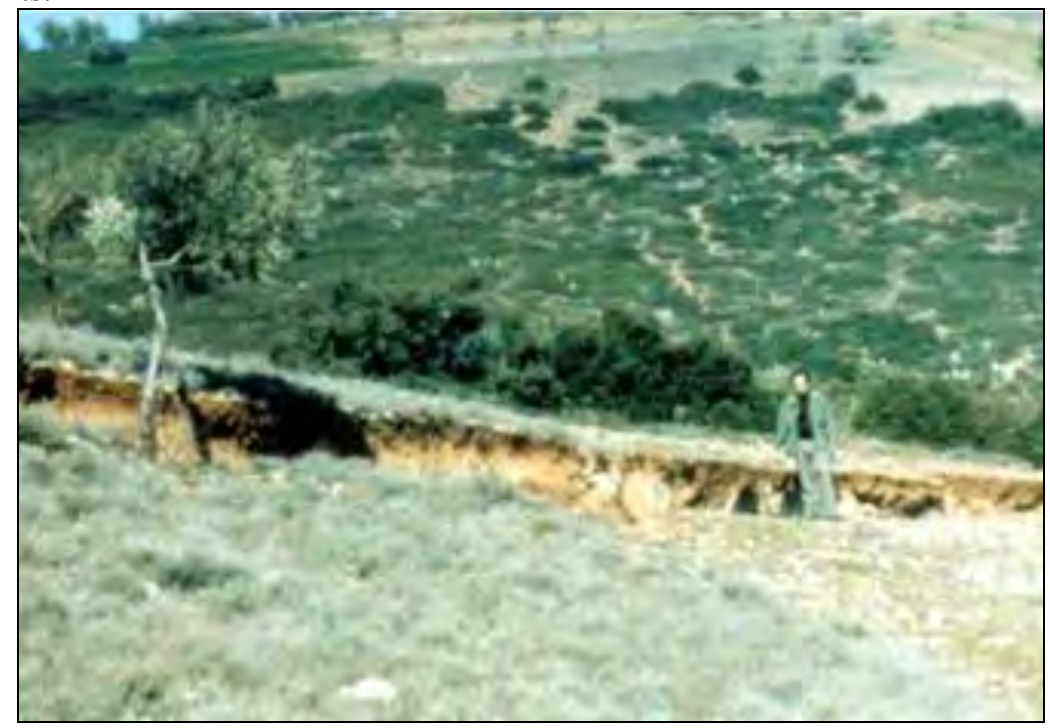

Figure 3 - View of the surface rupture in Kaparelli region. 


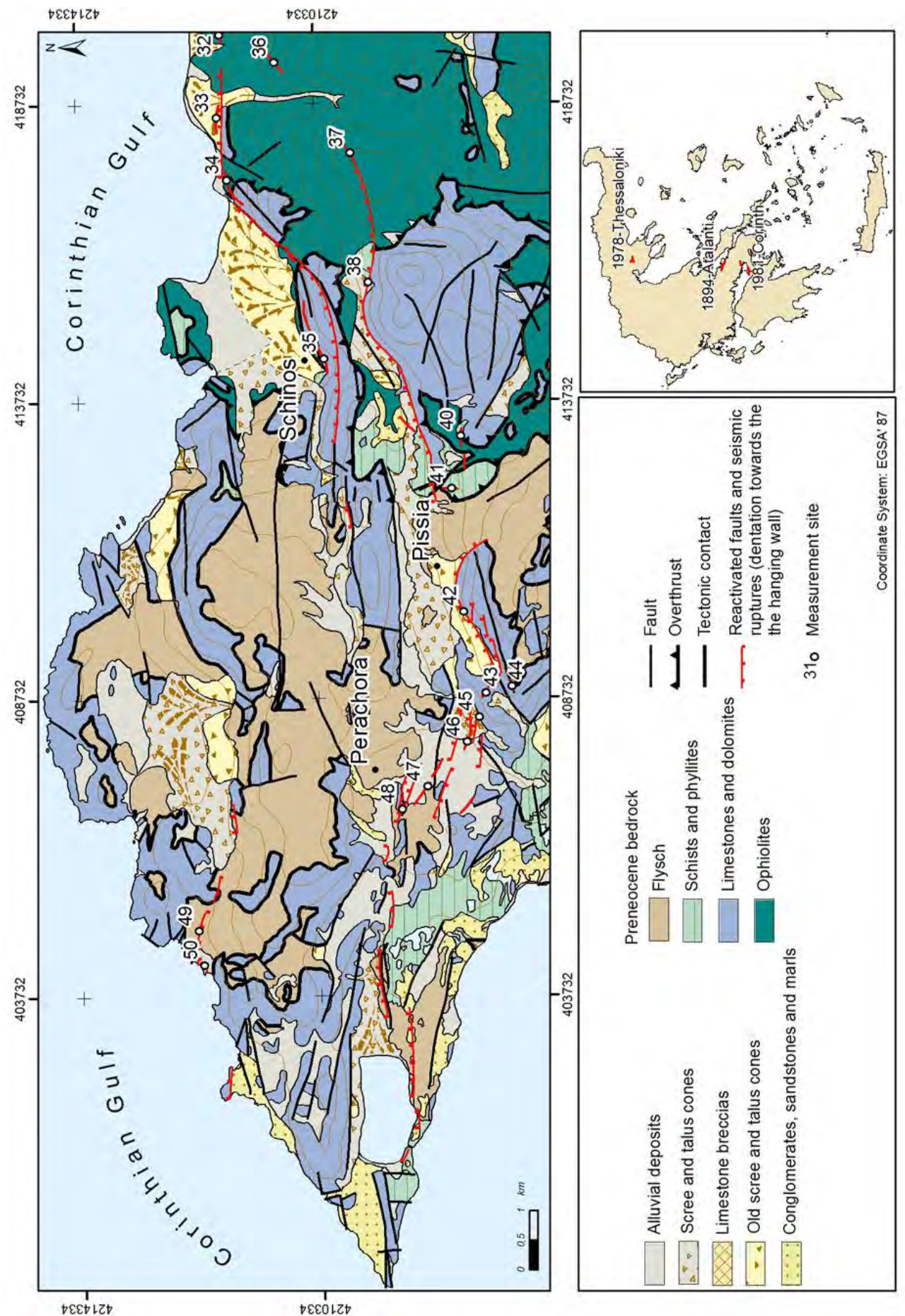

Figure 4 - Geological map of Perachora peninsula (southern part of the eastern Corinthian gulf) illustrating the 1981 seismic ruptures (based on the geological map of Greece in scale 1:50.000; Jackson et al., 1982; Rondoyanni \& Koukis, 1989). The numbers correspond to the sites where displacement data were available. In the inset map, the studied seismic faults are located. 


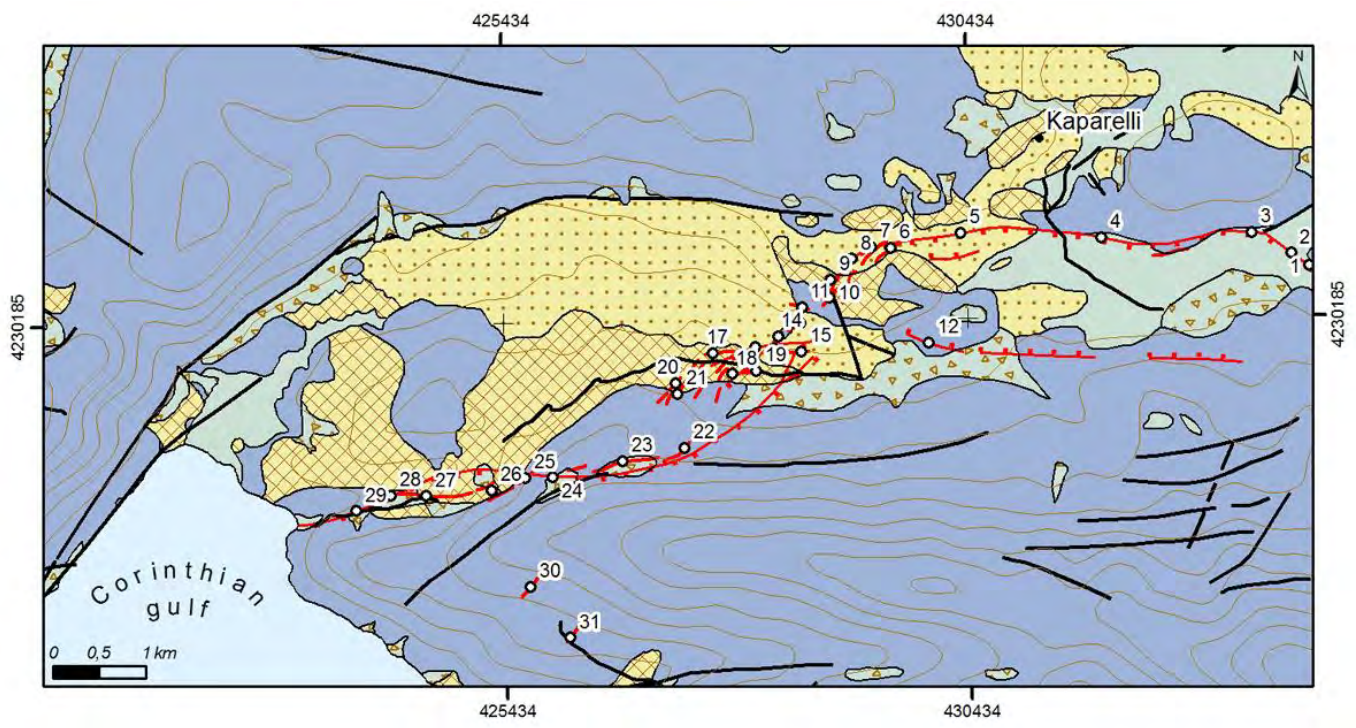

Figure 5 - Geological map of Kaparelli region (northern part of the eastern Corinthian gulf) illustrating the 1981 seismic ruptures (based on the geological map of Greece in scale 1:50.000; Jackson et al., 1982; Rondoyanni \& Koukis, 1989). The numbers correspond to the sites where displacement data were available. The geological formations as noted in Figure 4.

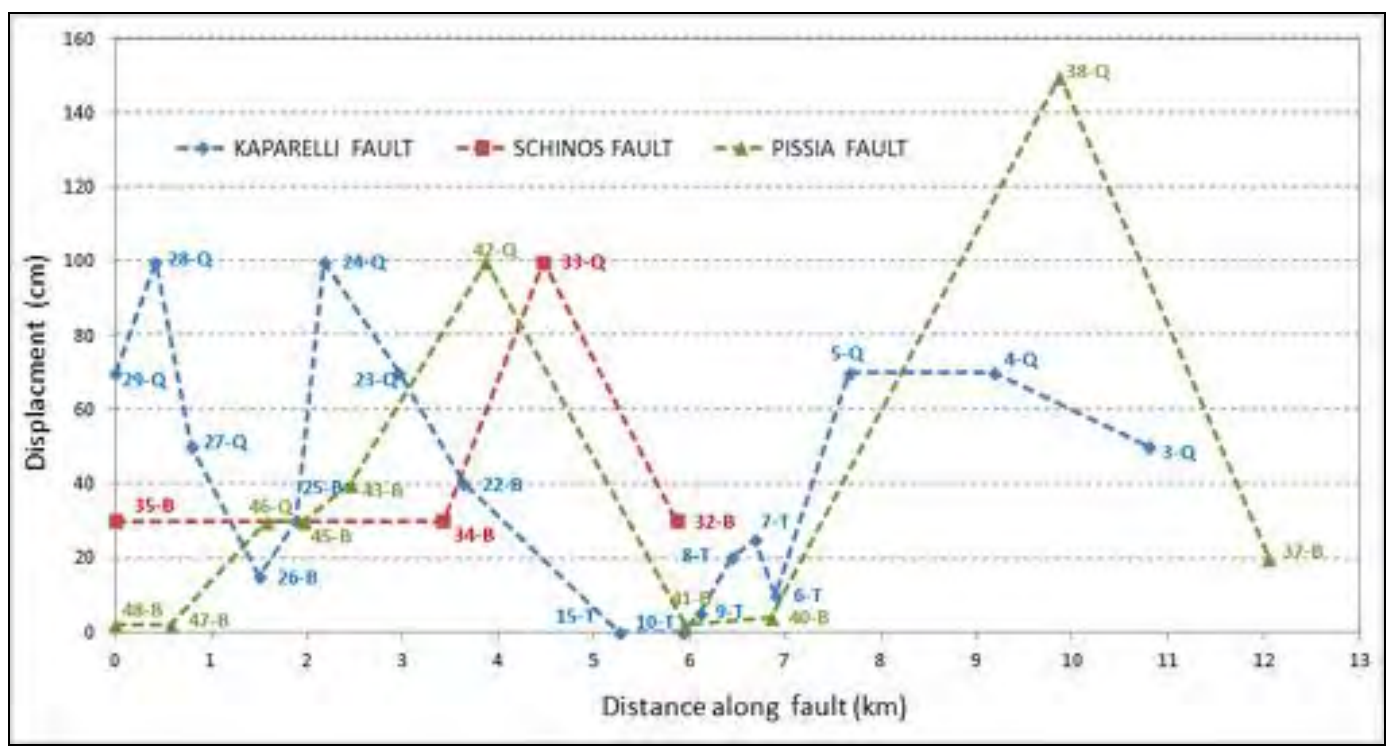

Figure 6 - Coseismic surface displacement along the 1981 reactivated faults (Schinos and Pissia faults are shown in Figure 4; Kaparelli fault in Figure 5). The numbers correspond to the sites noted also in Figures 4 and 5. Sites not presented in Figure 4 correspond to open seismic cracks with no vertical displacement. Lithology notation: B: Bedrock, Q: Quaternary unconsolidated geological formations, T:Transfer zone of Kaparelli fault. 


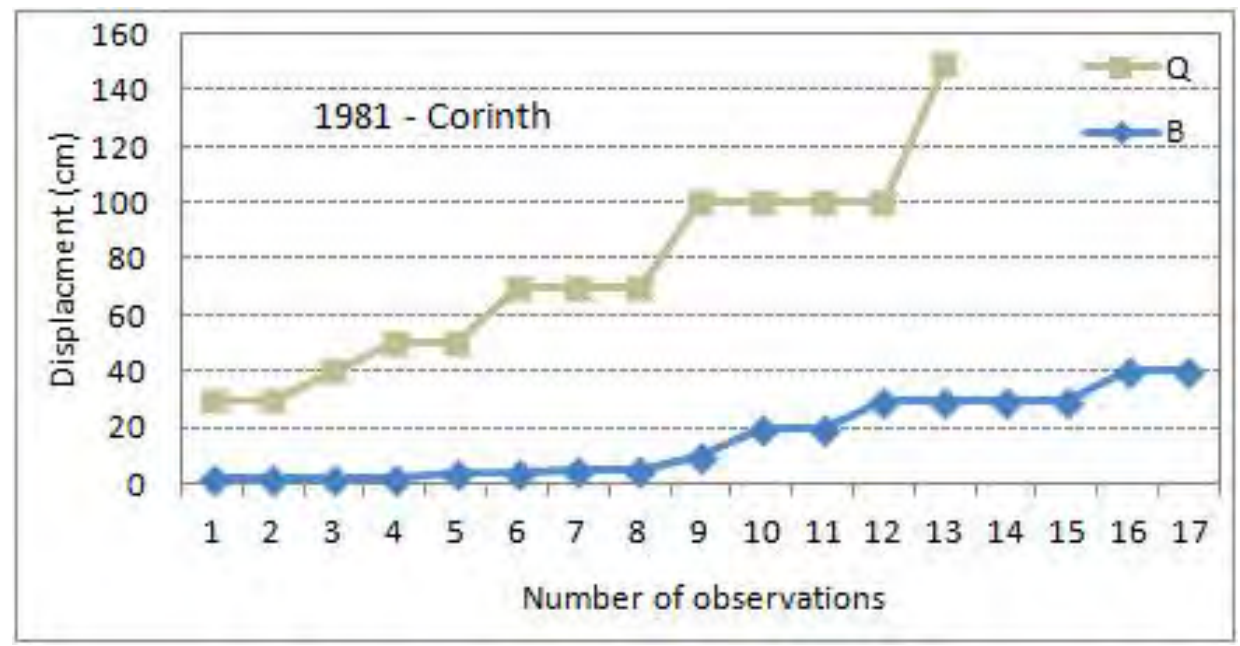

Figure 7 - Displacement of 1981 Corinth seismic ruptures in relation to lithology (B:Bedrock, Q:Quaternary unconsolidated geological formations).

As it concerns the magnitude of coseismic displacement according to existed relationships for the reactivated fault length of about $13 \mathrm{~km}$, an average displacement of $40 \mathrm{~cm}$ and a maximum displacement of $65 \mathrm{~cm}$ could be estimated, according to Wells and Coppersmith (1994) while according to Pavlides and Caputo (2004) the maximum displacement would be of the order of $45 \mathrm{~cm}$. The displacement measurements, in the Corinth epicentral area, showed displacements ranging from $30-60 \mathrm{~cm}$ in the bedrock and $120 \mathrm{~cm}$ in the quaternary deposits. Or, the correlation with the field data shows a good agreement of the estimated magnitudes with the measurements in the bedrock.

\subsection{The 1978 Thessaloniki earthquake}

During the 1978 Thessaloniki earthquake $(\mathrm{Ms}=6.5)$, seismic cracks were observed in the epicentral area, which is mainly covered by unconsolidated to medium consolidated formations such as alluvial deposits, scree and talus cones, lacustrine sediments and Plio-Pleistocene deposits (marls, clays, sandstones, conglomerates), while the geological bedrock consists of gneisses and schists (Figure 8). According to Mercier et al. (1983) and Mountrakis et al. (1983), along surface ruptures a maximum displacement of $20 \mathrm{~cm}$ was measured in the recent formations and a displacement of some centimeters in the gneisses (Figure 9). The length of each crack extended locally over a few hundred meters, but the total length of the deformed zone was about $12 \mathrm{~km}$ in length. It should be noted that the size of surface displacement appears to be smaller than this estimated according to existing relationships, considering both the magnitude of the earthquake and the length of the fault. This is maybe due to the fact that the seismic fault has caused diffuse surface deformation.

\subsection{The 1894 Atalanti earthquakes}

The seismic sequence of April 1894 consisted of two strong earthquakes of estimated size Ms=6.46.6 and $\mathrm{Ms}=6.9-7.0$. The reactivated fault was a normal fault striking ESE-WNW and dipping to the North. According to the descriptions concerning the surface displacement along the fault trace, measured in scattered locations, the highest value was observed to the boundary of the bedrock with the Atalanti alluvial plain (Skufos, 1894; Papavassiliou, 1894). The geological formations affected by the surface faulting are alluvial deposits, talus cones, neogene deposits (mainly marly limestones), mesozoic limestones and dolomites, palaeozoic clastic formations and ophiolites. According to existing data, the displacement ranges from $30 \mathrm{~cm}$ in the bedrock to $120 \mathrm{~cm}$ in the talus cones and alluvial deposits (Figure 9). The term "bedrock" includes the preneogene formations as well as well compacted Neogene deposits. 


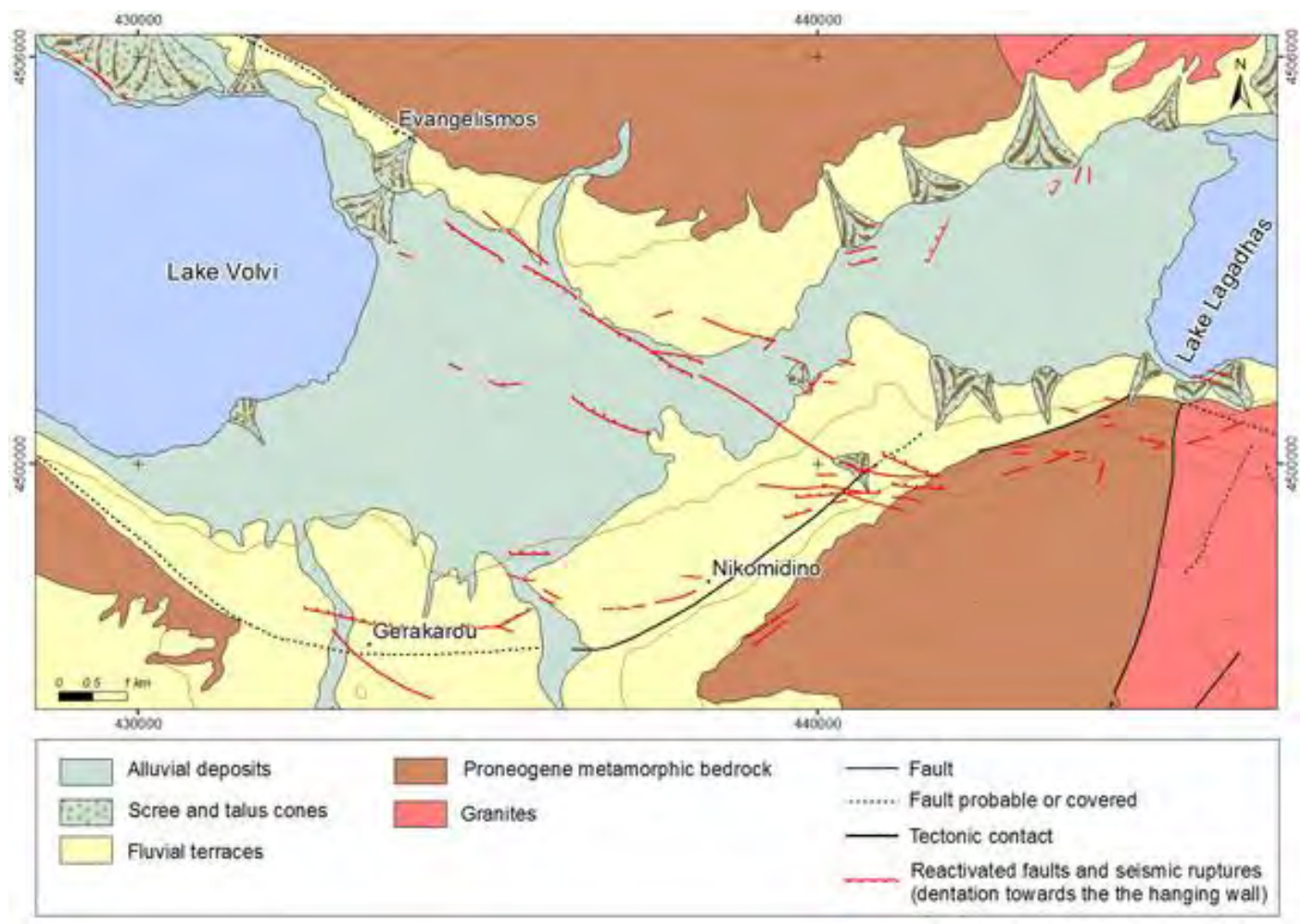

Figure 8 - Geological map of the epicentral Thessaloniki illustrating the 1978 seismic ruptures (based on the geological map of Greece in scale 1:50.000 - sheets Thermi and Zagliverio; Mercier et al., 1983; Mountrakis et al., 1983).

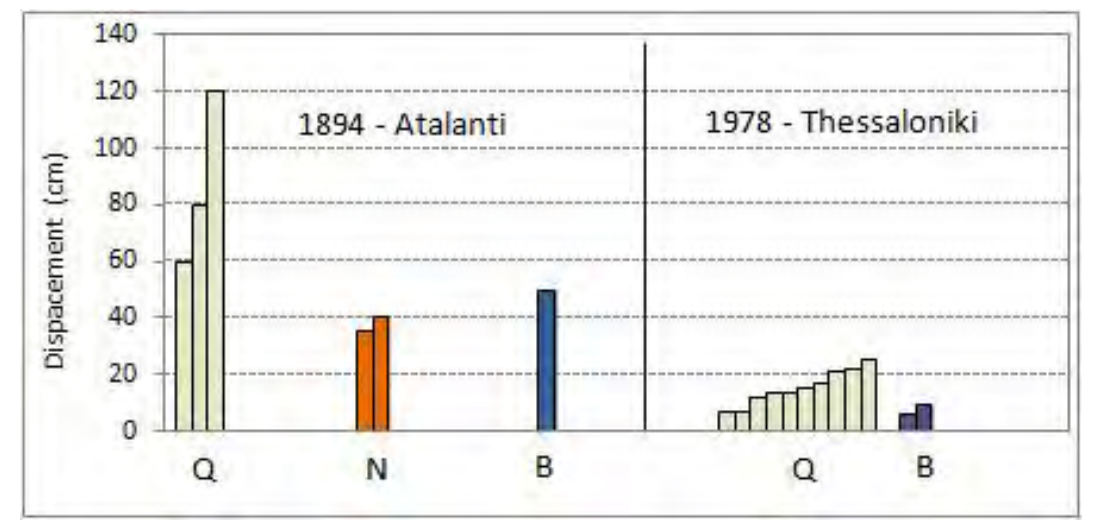

Figure 9 - Displacement of 1894 Atalanti and 1978 Thessaloniki seismic ruptures in relation to lithology (B:Bedrock, N:Neogene formations-mainly marly limestones, Q:Quaternary unconsolidated geological formations).

\section{Conclusions}

The estimation of the size of coseismic surface displacement along an active fault is an important factor for the assessment of fault activity and the resulting hazard. The existing empirical relationships between earthquake magnitude, fault length and seismic displacement are generally 
used for this estimation. However, the size of the displacement along a reactivated fault varies significantly, depending largely on the lithology of the geological formations affected by the seismic ruptures.

By correlating displacement size with lithology along a number of reactivated normal faults in the Aegean region, the following conclusions can be drawn:

- There is a strong correlation between coseismic surface displacement and regional lithology.

- The displacement observed in the recent geological formations (alluvial deposits, talus cones and unconsolidated basin infillings) is at least twice than that occurred in the geological bedrock (limestones, schists, gneisses, ophiolites). It must be noted that the ratio of maximum to minimun displacement values along a certain active fault could be high as 5:1. The term "bedrock" includes both the pre-neogene geological formations and the neogene compacted rocks as well; along the same fault, similar values of displacement have been observed in the mesozoic limestones and the neogene marly limestones.

- In certain cases, where seismic ruptures cross a strong morphology, the size of the displacement is enhanced by gravitational effects, while in the boundary between bedrock and alluvial deposits it may be amplified by the compaction of loose soil.

- The potential future displacements along the active faults determined on the basis of the existing empirical relationships are in accordance with those observed in the bedrock. This observation must be also taken into consideration in seismic hazard analysis during urban and engineering design in the vicinity of active faults.

\section{References}

Armijo R., Lyon-Caen H., and Papanastassiou D. 1991. A possible normal-fault rupture for the 464 BC Sparta earthquake, Nature, 351 (6322), 137-139.

Barka A., Akyuz H. S. 2002. The surface rupture and slip distribution of the 17 August 1999 Izmit earthquake (M7.4), North Anatolian fault, BSSA (Special Issue on the 1999 Izmit and Duzce, Turkey, Earthquakes, N. Toksoz (ed.)), 92(1), 43-60.

Billiris H., Paradissi D., Veis G., England P., Featherstone W., Parsons B., Cross P., Rands P., Rayson M., Sellers P., Ashkenazi V., Davison M., Jackson J. and Ambraseys N. 1991. Geodetic determination of tectonic deformation in central Greece from 1900 to 1988, Nature, $350,124-129$.

Jackson J.A., Gagnepain J., Houseman G., King P., Papadimitriou P., Soufleris C., Virieux, J. 1982. Seismicity, normal faulting and the geomorphological development of the Gulf of Corinth (Greece): the Corinth earthquakes, Earth Planet. Sci. Lett., 57, 377- 397.

IGME (Institute of Geology and Mineral Exploration) 1978. Geological map of Greece in scale 1:50.000, Sheets "Perachora" and "Kaparelli".

IGME (Institute of Geology and Mineral Exploration), 1984. Geological map of Greece in scale 1:50.000, Sheets "Thermi" and "Zagliveri".

Koukis G and Rozos D. 1982. Geological and geotechnical characteristics of the earthquakes of February-March 1981 in the Corinthian gulf, Proceedings of Athens Academy, 57, 406-425.

Mercier J.L., Carey-Gailhardis E., Mouyaris N., Simeakis K., Rondouyannis Th. and Anghelidhis Ch. 1983. Structural analysis of recent and active faults and regional state of stress in the epicentral area of the 1978 Thessaloniki earthguakes (Northern Greece), Tectonics, 2, 6, 577-600.

Mountrakis D., A. Psilovikos and Papazachos B. 1983. The geotectonic regime of the 1978 Thessaloniki earthquakes, in: Papazachos, B. C. and P. G. Carydis (eds.), The Thessaloniki, Northern Greece, earthquake of June 20, 1978 and its seismic sequence, Technical Chamber of Greece, 11 - 27.

Papavassiliou M.S. 1894. On the earthquakes of Lokris (Greece) April 1894, C. R. Ac. Scienc. Paris, T, CXIX:1. 
Papazachos B and Papazachou C., 2003. The Earthquakes of Greece, Ziti ed., Thessaloniki, 273 pp.

Pavlides S. and Caputo, R. 2004. Magnitude versus faults' surface parameters: uantitative relationships from the Aegean, Tectonophysics, 380(3-4), 159-188.

Rockwell T.K. and Klinger Y. 2011. The variability of along-strike co-seismic slip: A new example from Imperial fault of southern California. 2nd INQUA-IGCP-567 International Workshop on Active Tectonics, Earthquake Geology, Archaeology and Engineering, Corinth, Greece, 200-203.

Rondoyanni Th. and Koukis G. 1989. Neotectonics and recent seismic activity in the eastern Corinthian gulf, Greece. Geotechnical implications, Bull. AFEQ, 2me serie, n 39, 171-180.

Sigbjörnsson R. and Olafsson S. 2004. On the South Iceland earthquakes in June 2000: Strongmotion effects and damage, Bollettino di Geofisica Teorica e Applicata. 45, 131-152.

Skufos Th. 1894. Die zwei grossen Erdbeben in Lokris am 8/20 und 15/27 April 1984, Zeitschrift Ges. Erdkunde zu Berlin, vol. 29. 409 pp.

Wells D. and Coppersmith K. 1994. New empirical relationships among magnitude, rupture length, rupture width, rupture area, and surface displacement, B.S.S.A., 84, 974-1002. 